\title{
Upaya membangun keterampilan proses sains melalui pembelajaran inkuiri berbantuan alat peraga gaya sentripetal
}

\author{
Ridho Adi Negoro \\ ${ }^{1}$ Pendidikan Fisika, Pascasarjana Universitas Negeri Semarang, Semarang 50237, Indonesia \\ e-mail: rannegoro@gmail.com
}

\begin{abstract}
Abstrak
Pemahaman konsep tentang fisika akan lebih mudah diterima oleh siswa apabila mereka memiliki keterampilan proses sains. Pembelajaran inkuiri adalah salah satu alternatif untuk membangun keterampilan proses sains ini. Materi fisika gaya sentripetal dianggap oleh siswa identik dengan persamaan matematis, maka peneliti mengupayakan penggunaan alat peraga gaya sentripetal untuk menunjang pembelajaran inkuiri. Tujuan penelitian ini adalah untuk membangun keterampilan proses sains siswa melalui pembelajaran inkuiri berbantuan alat peraga gaya sentripetal sehingga hasil belajar dapat meningkat. Rancangan penelitian menggunakan penelitian tindakan kelas yang terdiri dari 2 siklus. Masing-masing siklus terdiri dari langkah: perencanaan, implementasi, evaluasi dan refleksi yang mengadopsi model spiral dari Kemmis dan MC Taggart. Subjek penelitian adalah 27 siswa kelas X SMK NU Ungaran. Instrumen penelitian berupa lembar observasi, tes pilihan ganda dan tes essai. Teknik analisis data menggunakan deskriptif persentase. Hasil penelitian ini adalah sebagai berikut 1) terjadi peningkatkan ketrampilan proses sains pada siswa kelas X SMA melalui pembelajaran inkuiri menggunakan alat peraga dengan persentase ketercapaian keterampilan proses sains setelah CAR 89,34 \% 2) Terjadi peningkatan hasil belajar siswa kelas X SMA melalui pembelajaran inkuiri menggunakan alat peraga ditunjukan oleh nilai rata-rata tes essai setelah CAR sebesar 85,2 .
\end{abstract}

Kata Kunci: Alat Peraga; Gaya Sentripetal; Inkuiri; Keterampilan Proses Sains

\section{Efforts to build science process skills through inquiry learning with centripetal force props}

\begin{abstract}
Understanding the concept of physics will be more easily accepted by students if they have science process skills. Inquiry learning is an alternative method to building science process skill. Centripetal force physics material is considered by students to be identical with mathematical equations, so researchers seek the use of centripetal-style props to support inquiry learning. The purpose of this study is to build student science process skills through inquiry assisted by centripetal force props teaching aids so that learning outcomes can increase. The research design uses classroom action research consisting of 2 cycles. Each cycle consists of steps: planning, implementation, evaluation and reflection which adopt a spiral model from Kemmis and MC Taggart. The research subjects were 27 students of class X of SMK NU Ungaran. The research instrument was in the form of observation sheets, multiple choice tests and essay tests. The data analysis technique uses descriptive percentages The results of this study are as follows: 1) there is an increase in science process skills in class $X$ high school students through inquiry learning using teaching aids with the percentage of achievement of science process skills after CAR $89.34 \%$ 2) There is an increase in learning outcomes of class $X$ high school students through inquiry learning using teaching aids shown by average grades the essay test after the CAR is 85.2 .
\end{abstract}

Keywords: Teaching aids; Centripetal Force; Inquiry; Science Process Skills 
How to Cite: Negoro, R. (2019). Upaya Membangun Keterampilan Proses Sains Melalui Pembelajaran Inkuiri Berbantuan Alat Peraga Gaya Sentripetal. Jurnal Pendidikan Fisika dan Keilmuan (JPFK), 5(1), 45-52. doi:http://dx.doi.org/10.25273/jpfk.v5i1.3323

\section{PENDAHULUAN}

Pembelajaran fisika tidak dapat terlepas dari fenomena alam sekitar dari siswa. Pengalaman siswa untuk terjun langsung melakukan aktivitas yang berhubungan dengan fisika akan menjadi pertimbangan pemilihan suatu metode pembelajaran Fisika itu sendiri. Selain itu Pembelajaran fisika akan lebih bermakna jika calon guru terlibat aktif dalam pembelajaran (Nurussaniah, Trisianawati, \& Sari, 2017). Tujuan mempelajari IImu Pengetahuan Alam (IPA) yaitu agar siswa memiliki kemampuan mengembangkan pengetahuan dan pemahaman konsep IImu Pengetahuan Alam (IPA) yang bermanfaat dan dapat diterapkan dalam kehidupan sehari-hari dan mengembangkan keterampilan proses untuk menyelidiki alam sekitar, memecahkan masalah dan membuat keputusan serta mengembangkan rasa ingin tahu, sikap positif dan kesadaran tentang adanya hubungan yang saling mempengaruhi antara Ilmu Pengetahuan Alam (IPA), lingkungan, dan masyarakat. Pembelajaran Fisika harus mengikuti tujuan pembelajaran IPA, karena Fisika merupakan bagian dari IPA. Pengalaman langsung yang dilakukan oleh siswa akan mampu menumbuhkan kompetensi untuk memahami lingkungan sekitar secara ilmiah dan melalui inkuiri alamiah (scientific inquiry) siswa memiliki sikap ilmiah dan mengkomunikasikannya sebagai aspek penting kecakapan hidup (Ertikanto, 2017).

Model pembelajaran yang dapat digunanakan untuk mendekatkan siswa kepada fenomena fisika di alam adalah inquiry-based learning. Inquiry-based learning merupakan jenis pembelajaran yang memiliki strategi pembelajaran berpusat pada siswa (Gormally, Brickman, Hallar, \& Armstrong, 2009). Siswa secara aktif melakukan pencarian pengetahuan fisika baru bagi mereka melalui suatu langkah-langkah saintifik yaitu inkuiri berbasis sains akan meningkatkan keterampilan proses sains beserta pemahaman konsep. Inkuiri berbasis sains adalah salah satu pendekatan yang paling populer dalam kegiatan pembelajaran sains karena meningkatkan pemahaman konsep siswa serta keterampilan proses sains mereka (Lati, Supasorn, \& Promarak, 2012). Inkuiri berbasis sains dapat meningkatkan pemahaman siswa tentang topik kompleks di seluruh mata pelajaran sains dan konteks pengajaran. Karena inkuiri dirancang untuk menggantikan pembelajaran ceramah. Instruksi inkuiri yang memanfaatkan teknologi lebih efektif daripada instruksi biasa (Lee, Linn, Varma, \& Liu, 2010; Linn, Lee, Tinker, Husic, \& Chiu, 2006).

Pembelajaran inkuiri dapat ditunjang melalui berbagai media. Hasil penelitian (Siregar, 2013) menunjukan bahwa teradapat pengaruh antara model pembelajaran inkuiri berbasis media animasi terhadap pemahaman konsep, sikap ilmiah. Alternatif media lain yang dapat digunakan adalah modul atau bahan ajar dan alat peraga. Modul dapat mengembangkan keterampilan proses sains memalui penyesuaian modul dengan hakikat pembelajaran sains (Sumiati, Septian, \& Faizah, 2018). Alat peraga dapat membantu siswa dalam proses pembelajaran untuk memperoleh pengetahuan baru melalui panca indera mereka sehingga memunculkan sebuah persepsi dan memungkinkan digunakan siswa untuk membangun keterampilan proses sains. Penelitian tentang alat peraga oleh (Hasbi, 2015) memperoleh kesimpulan bahwa penggunaan alat peraga yang dapat menunjang pembelajaran inkuiri dapat meningkatkan penguasaan konsep siswa.

Menurut Dahar (2002) Keterampilan proses sains adalah kemampuan siswa untuk menerapkan metode ilmiah dalam memahami, menemukan dan 
mengembangkan ilmu pengetahuan. Keterampilan proses sains dapat dikategorikan menjadi dua level, yaitu dasar dan terintegrasi. Keterampilan proses sains terintegrasi terdiri dari lima keterampilan yaitu mengidentifikasi dan mengontrol variabel, mendefinisikan secara operasional, merumuskan hipotesis, bereksperimen termasuk mampu merancang eksperimen mereka sendiri untuk menguji hipotesis menggunakan prosedur untuk memperoleh data yang dapat diandalkan, dan menafsirkan data dan menarik kesimpulan. Disarankan bahwa guru tidak dapat mengharapkan peningkatan besar dalam bereksperimen keterampilan setelah berlatih hanya beberapa eksperimen. Sebaliknya, siswa membutuhkan banyak kesempatan untuk meningkatkan keterampilan ini dalam beberapa eksperimen (Padilla, 1990). Menurut Ergül et al. (2011), Keterampilan proses sains dasar dalam suatu pebelajaran dapat ditentukan oleh beberapa indikator yaitu mengamati, membandingkan dan mengklasifikasikan, menyimpulkan, memprediksi, menentukan operasional, mengukur, merekam dan menginterpretasi, merumuskan model, membuat tabel data dan grafik, sementara keterampilan proses yang terintegrasi adalah merumuskan hipotesis, mengidentifikasi dan mengontrol variabel dan bereksperimen.

\section{METODE PENELITIAN}

Metode Penelitian yang dipilih pada penelitian ini adalah Penelitian Tindakan Kelas, dengan subjek penelitian adalah 27 siswa kelas X SMK NU Ungaran. Waktu penelitian dilaksanakan pada semester genap tahun akademik 2017/2018. Pembelajaran dilakukan dengan menggunakan model pembelajaran inkuri mengadaptasi model (Bell, Urhahne, Schanze, \& Ploetzner, 2010) seperti pada Tabel 1. Data pada penelitian ini diperoleh dari hasil observasi terhadap keterampilan proses sains siswa, dan untuk mengetahui ketuntasan hasil belajar materi gaya sentripetal pada siswa dilakukan tes pilhan ganda dan tes essai. Data yang diperoleh dianalisis kemudian dideskripsikan dalam bentuk kuantitatif deskriptif. Indikator Keterampilan proses sains dirumus kan menjadi tiga belas yaitu 1) Observasi, 2) Klasifikasi, 3) Mengukur, 4) Menggunakan Hubungan Waktu/Ruang, 5) Menggunakan Bilangan, 6) Inferensi, 7) Komunikasi, 8) Memprediksi, 9) Mengidentifikasi dan Mengontrol Variabel, 10) Interpretasi Data, 11) Memformulasi Hipotesis, 12) Mendefinisikan secara Operasional, 13) Eksperimen. Keterampilan proses sains diukur melalui observasi pada saat eksperimen dan hasil laporan eksperimen siswa. Untuk menganalisis data hasil observasi keterampilan proses sains siswa yang mengacu indikator di atas, digunakan rumus:

$$
S_{\square}=\frac{S}{S_{m}} \times 100 \%
$$

(Arikunto, 2002)

\section{Keterangan :}

Skor dihitung dalam persentase (\%)

Skor maksimum $=49$

$S_{a}:$ Skor indikator ketrampilan proses sains dalam \%

$s$ : Skor indikator yang diperoleh

$S_{m}:$ Skor maksimum

Penelitian ini dilakukan 2 siklus yang masing-masing siklus terdiri dari langkah perencanaan, implementasi, evaluasi dan refleksi yang mengadopsi Model Spiral dari (Kemmis, McTaggart, \& Nixon, 2013) seperti pada gambar 1. 


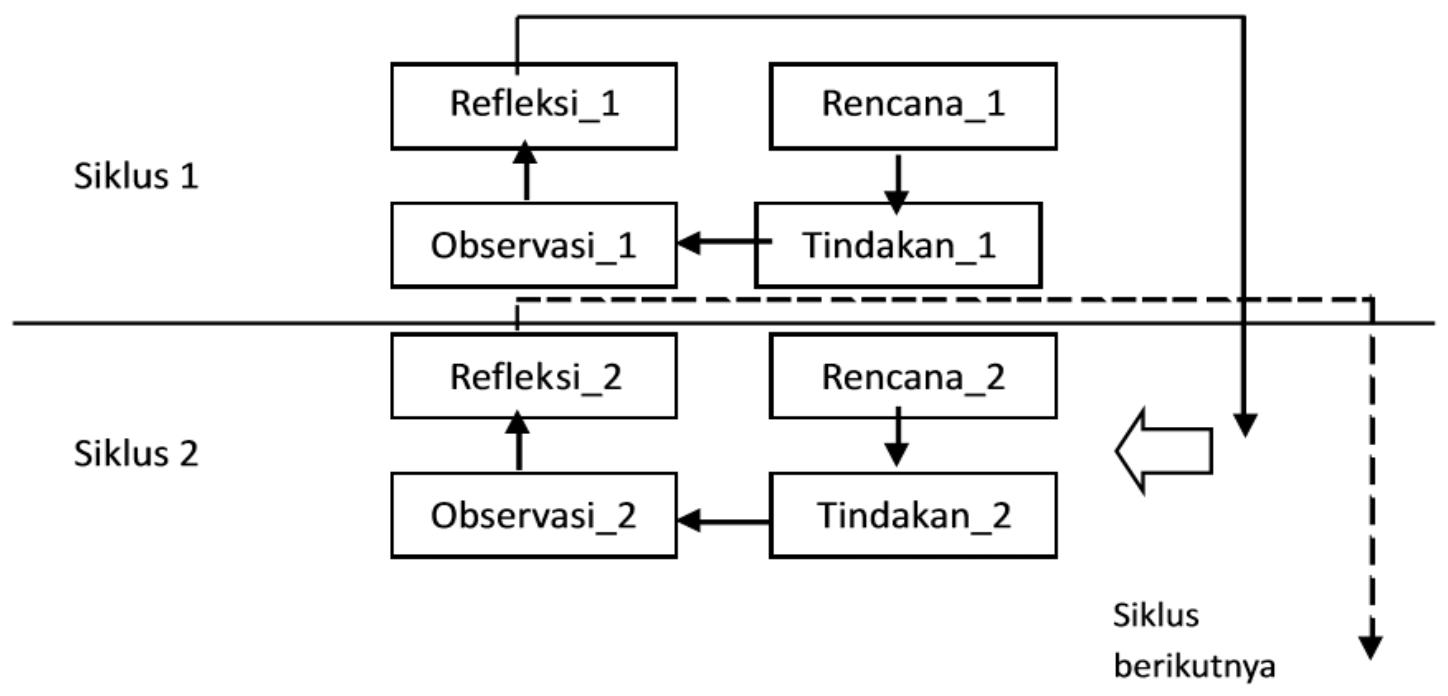

Gambar 1. Desain PTK menurut (Kemmis et al., 2013)

\section{HASIL DAN PEMBAHASAN}

Siswa menganggap pembelajaran fisika di sekolah memiliki kecenderungan penuh dengan rumus yang sulit untuk dipahami, bahkan banyak dari mereka yang tidak dapat menghubungkan antara pembelajaran fisika dengan kehidupan di sekitar mereka. Di dalam penelitian ini, masalah pembelajaran fisika yang sudah umum seperti itu dilakukan alternatif solusi yaitu pembelajaran inkuiri berbantuan alat peraga gaya sentripetal untuk menumbuhkan keterampilan proses sains yang pada akhirnya diharapkan mampu meningkatkan hasil belajar siswa. Penelitian lain yang memanfaatkan alat peraga untuk meningkatkan hasil belajar diantaranya (Yensy, 2012) dan (Hasbi, 2015). Alat peraga gaya sentripetal yang digunakan merupakan alat peraga yang ditujukan untuk mengetahui diantaranya hubungan variabel kecepata sudut, kecepatan linear, percepatan sudut, percepatan linear, percepatan sentripetat, dan gaya gesek pada fenomena gerak melingkar. Melalui pembelajaran inkuiri, alat peraga digunakan siswa sebagai media eksperimen dimana mereka menghubungkan antar variabel fisis pada gerak melingkar. Dari pembelajaran ini siswa akan aktif mengembangkan potensi berpikir untuk menemukan pengetahuan baru secara langsung melalui indera mereka dan secara tidak langsung menunmbuhkan keterampilan proses sains pada diri mereka.

Di dalam pembelajaran siswa dibentuk kelompok untuk mendiskusikan persoalan fisika yang diangkat dalam pembelajaran inkuiri dan mereka secara aktif menggali pengetahuan melalui eksperimen dengan alat peraga gaya sentripetal. Setiap kegiatan yang dilakukan oleh siswa diberikan perhatian oleh observer untuk dicatat dan diketahui seberapa jauh keterampilan proses sains yang mereka miliki. Hasil pada gambar 2 menunjukan bahwa terjadi peningkatan setiap aspek ketrampilan proses sains siswa dari siklus 1 hingga siklus II. Pada siklus 1 pembelajaran dilakukan dengan membagi siswa menjadi 6 kelompok, kemudian mereka bereksperimen menggunakan alat peraga gaya setripetal dengan tujuan menemukan hubungan antar variabel fisis dan besar koefisien gesek statis suatu bahan. Pada siklus ini, proses CAR masih belum maksimal dikarenakan banyak siswa yang masih belum siap dengan proses pembelajaran baru yang sangat berbeda dengan pembelajaran konvensional yang biasa mereka terima. Hal ini ditunjukan dengan banyak kelompok yang kehabisan waktu sebelum tujuan eksperimen tercapai. Menurut (Patchen, DeBay, Barnett, \& Strauss, 2014) 
tantangan pembelajaran inkuiri, yaitu pengantar dimana hal ini yang paling sulit untuk laboratorium sains, dan juga untuk menyediakan waktu untuk penyelidikan yang diperluas. Hasil penelitian oleh Gultepe and Kilic (2015) menunjukan Keterampilan proses ilmiah siswa dapat ditingkatkan melalui aktivitas meskipun beberapa (misalnya, merancang eksperimen) membutuhkan lebih banyak waktu dan upaya peningkatan kegiatan siswa. Perlu dicatat bahwa keterampilan proses sains melalui percobaan membutuhkan lebih banyak waktu dan energi yang digunakan. Hasil pada Tabel 1 menunjukan hasil observasi keterampilan proses sains sebanyak 16 siswa tidak tuntas. Hasil belajar di tunjukan oleh Tabel 2 yang didapatkan melalui tes pilihan ganda dan tes esai diberikan setelah siklus 1. Hasil tes menunjukan bahwa 8 siswa yang tidak tuntas. Berdasarkan siklus 1, peneliti merefleksi kekurangan dalam kesiapan siswa melakukan pembelajaran.

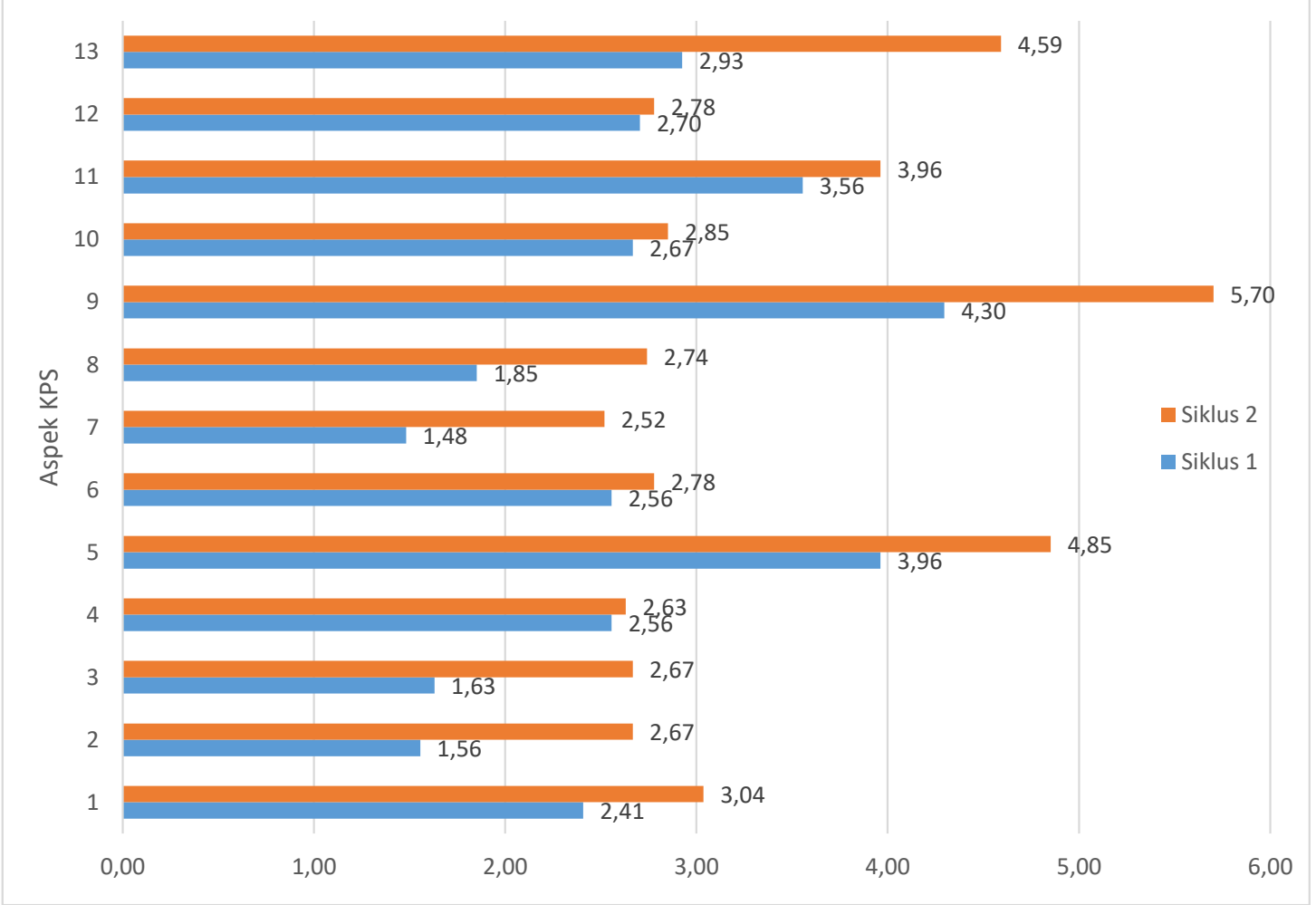

Gambar 2. Grafik Aspek Keterampilan Proses Sains

Tabel 1. Hasil Penilaian Ketrampilan Proses Sains Dalam Proses Pembelajaran

\begin{tabular}{|c|c|c|c|c|}
\hline No. & Jenis penilaian & Siklus 1 & Siklus 2 & Keterangan \\
\hline 1. & $\begin{array}{l}\text { Ketrampilan } \\
\text { Proses Sains }\end{array}$ & $69,69 \%$ & $89,34 \%$ & $\begin{array}{l}\text { Siklus 1: } 16 \text { Siswa belum tuntas } \\
\text { Siklus 2: Seluruh Siswa tuntas }\end{array}$ \\
\hline
\end{tabular}

Berdasarkan Tabel 1 dan 2, pada siklus 2 siswa mengalami peningkatan ketrampilan proses sains dan hasil belajar seluruh siswa tuntas. Aspek ke-9 yaitu mengidentifikasi dan mengontrol variabel memiliki peningkatan yang cukup tinggi, dan aspek ke-13 yaitu eksperimen hal ini dimungkinkan terjadi karena pada siklus II mereka mulai memahami makna dari setiap variabel fisis yang dikaji dari siklus I dan mereka sudah mampu melakukan setiap langkah eksperimen sesuai dengan tujuan. Kepemahaman siswa tentang variabel terlihat dari hasil olah data pada laporan setiap kelompok yang sudah jelas memunculkan variabel yang terkait dalam fenomena gerak melingkar dan terdapat kekonsistenan hasil pengukuran yang mereka dapat. 
Tabel 2. Nilai Rerata Hasil Belajar

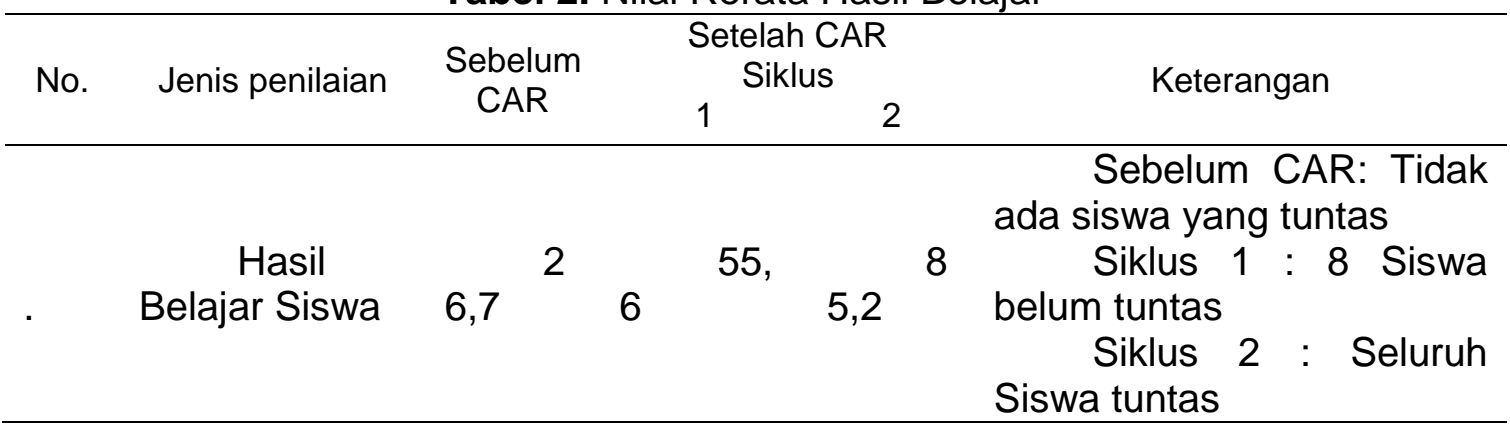

Ket: Ketuntasan Hasil Belajar > 70

Dari temuan di lapangan, agar ketrampilan proses sains dapat dimiliki melalui pembelajaran inkuiri, siswa harus memiliki rasa keingintahuan (curiosity) pada saat proses pembelajaran. Rasa keingintahuan ini yang akan memunculkan motivasi siswa untuk belajar (Patchen et al., 2014). Tantangan lain dalam pembelajaran inkuiri adalah bagaimana memotivasi siswa untuk terlibat dalam pembelajaran berbasis inkuiri. Dengan adanya motivasi pada siswa maak ketermapilan proses sains akan tumbuh. Hal ini sejalan dengan hasil penelitian Dwi (2016), dimana keterampilan proses sains fisika siswa pada kelompok motivasi tinggi lebih baik dibandingkan dengan keterampilan proses sains fisika siswa kelompok motivasi rendah.

Dari uraian hasil di atas dapat diketahui bahwa pembelajaran inkuiri berbantuan alat peraga dapat menumbuhkan ketrampilan proses sains. Hasil penelitian lain yang sejalan yaitu (Koksal \& Berberoglu, 2014) tentang Pembelajaran inkuiri yang mampu untuk menumbuhkan keterampilan proses sains, dan sikap ilmiah, hasil penelitian (Sen \& Sezen Vekli, 2016) dan (Adnyana \& Citrawathi, 2017) yang menunjukan bahwa pendekatan inkuiri dapat meningkatkan Keterampilan proses ilmiah, serta Ergül et al. (2011) yang menemukan bahwa keterampilan proses sains siswa yang menggunakan model belajar inkuiri lebih baik dibandingakan metode konvensional. Pembelajaran inkuiri dengan alat peraga juga mampu meningkatkan hasil belajar siswa, hal ini dimungkinkan terjadi karena pemahaman konsep siswa meningkat. Hal ini sesuai dengan temuan Alkan (2016) praktik pembelajaran pengalaman dimana siswa aktif dalam lapangan efektif meningkatkan prestasi akademik dan keterampilan proses ilmiah dan temuan (Şimşek \& Kabapınar, 2010) menemukan bahwa pembelajaran berbasis inkuiri memiliki dampak positif pada pemahaman konsep dan keterampilan proses ilmiah siswa. Strategi pengajaran yang memastikan partisipasi aktif siswa dengan bantuan penelitian ilmiah seperti pengalaman belajar meningkatkan pembelajaran konseptual lebih banyak bila dibandingkan dengan teknik yang lebih pasif (Ernst, 2013).

\section{KESIMPULAN}

Berdasarkan hasil penelitian, maka dapat disimpulkan bahwa pembelajaran inkuiri berbantuan alat peraga gaya sentripetal mampu meningkatkan keterampilan proses sains siswa disamping itu mampu meningkatkan hasil belajar siswa karena terjadi peningkatan pemahaman konsep. Kelemahan pembelajaran yang dapat diketahui dari penelitian ini adalah pengguanaan model inkuiri yang membuat siswa kesulitan memanajemen waktu. Hal tersebut dikarenakan siswa pertama kali menggunakan model ini. Sehingga perlu penigkatan efektivitas dan efisiensi 
metode pembelajaran melalui pemilahan materi atau sub materi yang perlu dipelajari atau segmentasi waktu eksperimen yang dilakukan secara proporsional.

\section{DAFTAR PUSTAKA}

Adnyana, P. B., \& Citrawathi, D. M. (2017). The Effectiveness of Question-Based Inquiry Module in Learning Biological Knowledge and Science Process Skills. International Journal of Environmental and Science Education.

Alkan, F. (2016). Experiential Learning: Its Effects on Achievement and Scientific Process Skills. Journal of Turkish Science Education (TUSED), 13(2).

Arikunto, S. (2002). Metodologi penelitian. Jakarta: Rineka Cipta.

Bell, T., Urhahne, D., Schanze, S., \& Ploetzner, R. (2010). Collaborative inquiry learning: Models, tools, and challenges. International Journal of Science Education, 32(3), 349-377.

Dahar, D. (2002). Teori-Teori Belajar. Jakarta: Erlangga.

Dwi, D. F. (2016). Efek Model Pembelajaran Inquiry Training Menggunakan Mind Mapping dan Motivasi Terhadap Keterampilan Proses Sains Fisika. UNIMED,

Ergül, R., Şımşeklı, Y., Çaliş, S., Özdılek, Z., Göçmençelebı, Ş., \& Şanli, M. (2011). The Effects of Inquiry-Based Science Teaching on Elementary School Students'science Process Skills And Science Attitudes. Bulgarian Journal of Science \& Education Policy, 5(1).

Ernst, J. V. (2013). Impact of Experiential Learning on Cognitive Outcome in Technology and Engineering Teacher Preparation. Journal of Technology Education, 24(2), 31-40.

Ertikanto, C. (2017). Development and Evaluation of a Model-Supported Scientific Inquiry Training Program for Elementary Teachers in Indonesia. International Journal of Instruction, 10(3), 93-108.

Gormally, C., Brickman, P., Hallar, B., \& Armstrong, N. (2009). Effects of inquiry-based learning on students' science literacy skills and confidence. International journal for the scholarship of teaching and learning, 3(2), 16.

Gultepe, N., \& Kilic, Z. (2015). Effect of Scientific Argumentation on the Development of Scientific Process Skills in the Context of Teaching Chemistry. International Journal of Environmental and Science Education, 10(1), 111-132.

Hasbi, M. A. (2015). Pengembangan Alat Peraga Listrik Dinamis (APLD) Berbasis Inkuiri Untuk Meningkatkan Penguasaan Konsep Siswa. Jurnal Penelitian Pendidikan IPA, 1(1).

Kemmis, S., McTaggart, R., \& Nixon, R. (2013). The action research planner: Doing critical participatory action research: Springer Science \& Business Media.

Koksal, E. A., \& Berberoglu, G. (2014). The effect of guided-inquiry instruction on 6th grade Turkish students' achievement, science process skills, and attitudes toward science. International Journal of Science Education, 36(1), 66-78.

Lati, W., Supasorn, S., \& Promarak, V. (2012). Enhancement of learning achievement and integrated science process skills using science inquiry learning activities of chemical reaction rates. Procedia-Social and Behavioral Sciences, 46, 44714475.

Lee, H. S., Linn, M. C., Varma, K., \& Liu, O. L. (2010). How do technology-enhanced inquiry science units impact classroom learning? Journal of Research in Science Teaching: The Official Journal of the National Association for Research in Science Teaching, 47(1), 71-90.

Linn, M. C., Lee, H.-S., Tinker, R., Husic, F., \& Chiu, J. L. (2006). Teaching and assessing knowledge integration in science. Science, 313(5790), 1049-1050. 
Nurussaniah, N., Trisianawati, E., \& Sari, I. N. (2017). Pembelajaran Inkuiri untuk Meningkatkan Keterampilan Proses Sains Calon Guru Fisika. Jurnal IImiah Pendidikan Fisika Al-BiRuNi, 6(2), 233-240.

Padilla, M. J. (1990). The science process skills. Research Matters-to the science Teacher, 9004.

Patchen, A. K., DeBay, D. J., Barnett, M., \& Strauss, E. (2014). Engaging students in scientific inquiry: successes and challenges of engaging non-science majors in scientific inquiry. In Inquiry-based learning for faculty and institutional development: A conceptual and practical resource for educators (pp. 271-289): Emerald Group Publishing Limited.

Sen, C., \& Sezen Vekli, G. (2016). The Impact of Inquiry Based Instruction on Science Process Skills and Self-Efficacy Perceptions of Pre-Service Science Teachers at a University Level Biology Laboratory. Universal Journal of Educational Research, 4(3), 603-612.

Şimşek, P., \& Kabapınar, F. (2010). The effects of inquiry-based learning on elementary students' conceptual understanding of matter, scientific process skills and science attitudes. Procedia-Social and Behavioral Sciences, 2(2), 1190-1194.

Siregar, S. (2013). Pengaruh Model Pembelajaran Inkuiri Berbasis Media Animasi Terhadap Pemahaman Konsep, Sikap Ilmiah Dan Assesmen Kinerja Siswa Pada Konsep Sintesis Protein. Jurnal EduBio Tropika, 1(2).

Sumiati, E., Septian, D., \& Faizah, F. (2018). Pengembangan modul fisika berbasis Scientific Approach untuk meningkatkan Keterampilan Proses Sains siswa. Jurnal Pendidikan Fisika dan Keilmuan (JPFK), 4(2), 75-88.

Yensy, N. A. (2012). Penerapan model pembelajaran kooperatif tipe examples non examples dengan menggunakan alat peraga untuk meningkatkan hasil belajar siswa di kelas VIII SMP N 1 Argamakmur. Exacta, 10(1), 24-35. 